University of South Carolina

Scholar Commons

7-8-2014

\title{
Effects of Nutritional Level of Concentrate-Based Diets on Meat Quality and Expression Levels of Genes Related to Meat Quality in Hainan Black Goats
}

\author{
Dingfa Wang \\ Chinese Academy of Tropical Agricultural Sciences \\ Luli Zhou \\ Chinese Academy of Tropical Agricultural Sciences \\ Hanlin Zhou \\ Chinese Academy of Tropical Agricultural Sciences \\ Guanyu Hou \\ Chinese Academy of Tropical Agricultural Sciences \\ Liguang Shi \\ Chinese Academy of Tropical Agricultural Sciences
}

See next page for additional authors

Follow this and additional works at: https://scholarcommons.sc.edu/biol_facpub

Part of the Cell Biology Commons, Meat Science Commons, and the Sheep and Goat Science Commons

\section{Publication Info}

Postprint version. Published in Animal Science Journal, Volume 86, Issue 2, 2014, pages 166-173.

(c) Animal Science Journal 2014, Japanese Society of Animal Science.

This Article is brought to you by the Biological Sciences, Department of at Scholar Commons. It has been accepted for inclusion in Faculty Publications by an authorized administrator of Scholar Commons. For more information, please contact digres@mailbox.sc.edu. 


\section{Author(s)}

Dingfa Wang, Luli Zhou, Hanlin Zhou, Guanyu Hou, Liguang Shi, Mao Li, Xianzhou Huang, and Song Guan 


\title{
ORIGINALARTICLE
}

\section{Effects of nutritional level of concentrate-based diets on meat quality and expression levels of genes related to meat quality in Hainan black goats}

\author{
Dingfa WANG, Luli ZHOU, Hanlin ZHOU, Guanyu HOU, Liguang SHI, Mao LI, Xianzhou HUANG and \\ Song GUAN
}

Tropical Crops Genetic Resources Institute, Chinese Academy of Tropical Agricultural Sciences, Danzhou, China

\begin{abstract}
The present study investigated the effects of the nutritional levels of diets on meat quality and related gene expression in Hainan black goat. Twenty-four goats were divided into six dietary treatments and were fed a concentrate-based diet with two levels of crude protein (CP) (15\% or 17\%) and three levels of digestive energy (DE) $(11.72,12.55$ or $13.39 \mathrm{MJ} / \mathrm{kg} \mathrm{DM})$ for 90 days. Goats fed the concentrate-based diet with $17 \%$ CP had significantly $(P<0.05)$ higher average daily gains $(A D G)$ and better feed conversion rates (FCR). The $\mathrm{pH}_{24 \mathrm{~h}}$ value tended to decrease $(P<0.05)$ with increasing $D E$ levels. The tenderness of Longissimus dorsi muscle (LD) and Semimembranosus muscle (SM) reduced with increasing CP levels $(P<0.05)$. With increasing DE levels, tenderness was increased $(P<0.05)$. The heart fatty acid-binding protein (H-FABP) mRNA expression levels in LD and SM increased with increasing DE levels $(P<0.05)$, but decreased with increasing CP levels $(P<0.05)$. The calpastatin (CAST) and $\mu$-calpain mRNA expressions levels in LD and SM were affected significantly $(P<0.05)$ by $C P$ and $D E$ levels in the diet. Therefore, the nutritional levels of diets affect meat quality and expression levels of genes associated with meat quality in Hainan black goats.
\end{abstract}

Key words: calpastatin, Hainan black goat, heart fatty acid-binding protein, meat quality, $\mu$-calpain.

\section{INTRODUCTION}

Goats are good sources of lean meat. Goats store higher proportions of polyunsaturated fatty acids in their tissues (Mushi et al. 2008). The demand for goat production will continue to increase in the future (Kannan et al. 2006). Goats fed concentrate-based diets generally have higher growth rates, dressing percentage and carcass quality than goats that are grassfed (Kosum et al. 2003). Furthermore, goats fed on suitable nutrition levels of concentrate-based diets have coordinated meat quality with those goats fed mainly on pasture (Kannan et al. 2006). Several studies have shown that the nutritional level of diets can affect meat quality and the expression levels of genes associated with meat quality (Patterson et al. 2009; Hocquette et al. 2010; Guo et al. 2011).

Hainan black goat, a meat goat breed, is raised in the south of China. This breed is not only tolerant to the warm and rainy climates of the region, it is also a source of delicious meat. In the past, Hainan black goats grazed freely. Recently, in an attempt to protect the environment and develop large-scale farming, goats have been confined. This breed of goat has great flaws with slow growth rates and small body sizes; however, goat meat remains very popular in the south of China due to its delicious flavors.

Heart fatty acid-binding protein (H-FABP) has been associated with intramuscular fat (IMF) content (Gerbens et al. 1999). Even though H-FABP is widely distributed, the heart and skeletal muscle tissue have the greatest expression levels (Li et al. 2007). H-FABP may play an important role in the development of intramuscular adipocytes. Certain enzymes are associated with meat tenderness; for example, $\mu$-calpain is an enzyme largely responsible for postmortem muscle proteolysis (Geesink et al. 2006) and calpastatin (CAST) is an enzyme that decreases muscle proteolysis by inhibiting the action of $\mu$-calpain (Goll et al. 2003).

Few studies have been conducted to assess the effect of nutritional level of diets on growth performance

Correspondence: Hanlin Zhou, Tropical Crops Genetic Resources Institute, Chinese Academy of Tropical Agricultural Sciences, Danzhou 571737, China. (Email: zhouhanlin8@163.com)

Received 19 October 2013; accepted for publication 10 April 2014. 
Table 1 Composition and nutrient levels of concentrate diets, as-fed basis

\begin{tabular}{|c|c|c|c|c|c|c|}
\hline \multirow{2}{*}{$\begin{array}{l}\mathrm{CP}(\%) \\
\mathrm{DE}(\mathrm{MJ} / \mathrm{kg})\end{array}$} & \multicolumn{3}{|c|}{15} & \multicolumn{3}{|c|}{17} \\
\hline & 11.72 & 12.55 & 13.39 & 11.72 & 12.55 & 13.39 \\
\hline \multicolumn{7}{|l|}{ Ingredients (\%) } \\
\hline Maize & 53.00 & 61.00 & 74.00 & 48.00 & 59.00 & 68.50 \\
\hline Soy bean meal & 19.50 & 19.00 & 19.50 & 26.00 & 25.00 & 25.50 \\
\hline Wheat bran & 12.50 & 10.00 & 0.50 & 10.00 & 6.50 & - \\
\hline Chaff & 9.00 & 4.00 & - & 10.00 & 3.50 & - \\
\hline Stone dust & 0.50 & 0.50 & 0.50 & 0.50 & 0.50 & 0.50 \\
\hline Salt & 1.00 & 1.00 & 1.00 & 1.00 & 1.00 & 1.00 \\
\hline Sodium bicarbonate & 0.50 & 0.50 & 0.50 & 0.50 & 0.50 & 0.50 \\
\hline Premix $†$ & 4.00 & 4.00 & 4.00 & 4.00 & 4.00 & 4.00 \\
\hline \multicolumn{7}{|l|}{ Nutrition level $\ddagger$} \\
\hline Dry matter (\%) & 87.67 & 87.53 & 87.37 & 87.86 & 87.67 & 87.55 \\
\hline $\mathrm{DE}(\mathrm{MJ} / \mathrm{kg})$ & 11.80 & 12.60 & 13.39 & 11.78 & 12.58 & 13.40 \\
\hline Crude protein (\%) & 15.08 & 15.05 & 14.99 & 17.14 & 17.08 & 17.08 \\
\hline Ether extract $(\%)$ & 2.35 & 2.85 & 3.14 & 2.77 & 3.75 & 3.95 \\
\hline $\operatorname{NDF}(\%)$ & 12.26 & 12.01 & 9.80 & 12.15 & 12.35 & 9.91 \\
\hline $\operatorname{ADF}(\%)$ & 5.35 & 5.26 & 4.53 & 5.48 & 5.31 & 4.85 \\
\hline Calcium (\%) & 0.78 & 0.79 & 0.80 & 0.79 & 0.80 & 0.81 \\
\hline Phosphorous (\%) & 0.37 & 0.36 & 0.31 & 0.36 & 0.36 & 0.33 \\
\hline
\end{tabular}

tThe premix provides the following per kg of diet: vitamin A $15000 \mathrm{IU}$, vitamin D $5000 \mathrm{IU}$, vitamin E $50 \mathrm{mg}, \mathrm{Fe} 9 \mathrm{mg}, \mathrm{Cu} 12.5 \mathrm{mg}, \mathrm{Zn}$ $100 \mathrm{mg}$, Mn $130 \mathrm{mg}$, Se $0.3 \mathrm{mg}$, I $1.5 \mathrm{mg}$, Co $0.5 \mathrm{mg}$. ‡The nutrient levels are measured values not including DE. CP, crude protein; DE, digestible energy; NDF, neutral detergent fiber; ADF, acid detergent fiber.

and meat quality of Hainan black goats, a local goat breed in South China. Therefore, our objective was to determine the effects of the nutritional level of diets on meat quality and expression of genes associated with meat quality in Hainan black goats.

\section{MATERIALS AND METHODS Animals and treatments}

The animal experiment was approved by the Institutional Animal Care and Use Committee at the Chinese Academy of Tropical Agricultural Sciences in Haikou, China. The experiment was conducted in accordance with the National Institute of Health guidelines for the care and use of experimental animals.

The experiment had a $2 \times 3$ factorial design using a concentrate-based diet with a crude protein (CP) level of $15 \%$ or $17 \%$, and a digestible energy (DE) level of 11.72 , 12.55 or $13.39 \mathrm{MJ} / \mathrm{kg}$. The ingredients and chemical composition of the concentrate-based diet are listed in Table 1. Twenty-four castrated Hainan black goats ( 3 months old and $10.56 \pm 1.28 \mathrm{~kg}$ body weight $(\mathrm{BW})$ ) were randomly allocated to six dietary treatments, and each treatment was replicated four times with one goat per replicate.

\section{Physical and chemical composition of the concentrate-based diet and of King grass}

The physical and chemical composition of concentrate-based diet and of King grass was determined according to the method of the AOAC (2000). The composition and nutritional levels of the diets are shown in Tables 1 and 2.

\section{Feeding and management}

Animals were given a 15-day adaptation period during which they were treated with ivermectin against internal
Table 2 Chemical composition of King grass (air-dry basis)

\begin{tabular}{lc}
\hline Items & Content $(\%)$ \\
\hline Dry matter & 22.50 \\
Crude protein & 8.27 \\
Ether extract & 1.04 \\
Crude ash & 3.26 \\
Neutral detergent fiber & 66.22 \\
Acid detergent fiber & 42.97 \\
Calcium & 0.10 \\
Phosphorous & 0.15 \\
\hline
\end{tabular}

and external parasites. Fresh King grass (Pennisetum purpureum $\times$ P.americanum $c$. Reyan No.4; its chemical composition is shown in Table 2) and the concentrate-based diet were fed twice daily ( 08.30 and 15.00 hours). The goats were fed the concentrate-based diet followed by the grass. Water was freely available to the goats. During the experimental period (90 days) animals were stall-fed in individual pens. Feeding allocations and refusals to eat were recorded daily for each goat. Each month, the goats were weighed before the morning feeding.

\section{Slaughter and samples collection}

Goats were weighed on two consecutive days before slaughter to obtain the final live weight (FLW). Then they were fasted for $16 \mathrm{~h}$ and weighed again to obtain the slaughter live weight (SLW). The slaughter was performed over three consecutive days.

Approximately $100 \mathrm{~g}$ of Longissimus dorsi muscle tissue (LD, fifth lumbar vertebra region) and $100 \mathrm{~g}$ of Semimembranosus muscle tissue (SM) were removed from the left sides of carcasses and stored at $-20^{\circ} \mathrm{C}$ for subsequent IMF determination.

For total RNA extraction, the LD and SM samples, obtained from the left side of the carcass within 15 min after 
slaughter, were immediately frozen in liquid nitrogen and stored at $-80^{\circ} \mathrm{C}$ until analysis.

Two $5 \times 2.5 \times 2.5 \mathrm{~cm}$ chops of LD and SM, respectively, were obtained from the right side of the carcass along the direction of the muscle fibers within 45 min after slaughter, and stored at $-20^{\circ} \mathrm{C}$ for $24 \mathrm{~h}$. These chops were used in the determination of Warner-Bratzler shear force (WBSF).

\section{Muscle property}

Two $2.5 \mathrm{~cm}$ thick chops of LD and SM were obtained. The first chop was used for $\mathrm{pH}$ measurement approximately $45 \mathrm{~min}$ and $24 \mathrm{~h}$ postmortem using a penetrating electrode (Mettler Toledo, Changzhou, China) attached to a portable $\mathrm{pH}$-meter (FG2, Shanghai, China). The $\mathrm{pH}$ probe was calibrated with $\mathrm{pH} 4$ and $\mathrm{pH} 7$ standard buffer solutions. The chop was then stored at $4^{\circ} \mathrm{C}$ for $24 \mathrm{~h}$ before the final $\mathrm{pH}$ measurement. The second chop was weighed, placed in a Whirlpak bag, suspended in a $4^{\circ} \mathrm{C}$ cooler for $24 \mathrm{~h}$, and then reweighed. Chop drip loss was calculated based on the weight loss; drip loss was expressed as percentage.

$\mathrm{LD}$ and SM chops (aged $24 \mathrm{~h}$ at $-20^{\circ} \mathrm{C}$ ) were thawed for $16 \mathrm{~h}$ at $4^{\circ} \mathrm{C}$ and then cooked to an internal temperature of $70^{\circ} \mathrm{C}$ in a thermostatic water-bath set at $80^{\circ} \mathrm{C}$. After removal from the water bath, LD and SM chops (two chops in every muscle, respectively) were allowed to cool to $4^{\circ} \mathrm{C}$, and then two $5 \times 1 \times 1 \mathrm{~cm}$ chops from each chop were cut parallel to the orientation of the muscle fiber. Each chop was then sheared four times at a crosshead speed of $1 \mathrm{~mm} / \mathrm{s}$ using a Texture Measurement System (Food Technology Corporation, Stirling, VA, USA). WBSF for individual chops were averaged for each sample, and then were averaged over four replicates for each dietary treatment (Guo et al. 2011).

Approximately $50 \mathrm{~g}$ of LD and SM samples were thawed for $16 \mathrm{~h}$ at $4^{\circ} \mathrm{C}$. External fat and connective tissue were removed prior to homogenization. Samples were placed in a drying oven at $65^{\circ} \mathrm{C}$ for at least $48 \mathrm{~h}$ and then IMF was extracted in petroleum ether using an automated extraction system (Gerhardt, Bonn, Germany).

\section{RNA extraction and mRNA expressions}

Total RNA was extracted using a commercial kit (Bioteke Corporation, RP1201, Beijing, China). Purity and concentration of RNA was checked with the RNA 6000 Nano LabChip kit using a bioanalyzer (Agilent Technologies, Shanghai, China). Total RNA $(2 \mu \mathrm{g})$ was used in a $20 \mu \mathrm{L}$ reverse tran- scription reaction volume (Bioteke Corporation). The resulting cDNA was diluted to $200 \mu \mathrm{L}$ with diethylpyrocarbonate (DEPC)-treated water and stored at $-20^{\circ} \mathrm{C}$.

The cDNA was amplified by real-time PCR using SYBR green real-time PCR master mix (Fermentas, Burlington, Canada) according to the manufacturer's instructions. All the primer sequences are listed as follows: glyceraldehyde-3phosphate dehydrogenase (GAPDH), 3'- ACCTTCACTACAT GGTCTAC, 5'- CTTTCCATTGATGACGAGCTTC, amplification length $101 \mathrm{bp}$, accession no. AJ431207.1; H-FABP, 3'TGGAAGTTAGTGGACAGC, 5'- GATTGTGGTAGGTTTGGTC, amplification length 102 bp, accession no. AY466498.1; CAST, 3'- GCACCCCTCAGATACAAGAAGC, 5'- TTTGGTT TTGTTGATTTCTCTG, amplification length $89 \mathrm{bp}$, accession no. GU944861.1; $\mu$-calpain, 3'- TCCTGCACCGAGTAGTTC, 5'- TCCACCCACTCACCAAACTGC, amplification length 94 bp, accession no. HQ718593.1. GAPDH gene was used as an internal control. The melting peaks of the amplification products were determined by melting curve analyses in order to ascertain that only the expected amplification products had been generated. Relative gene expression levels were presented as $2^{-\Delta \Delta \mathrm{CT}}$; the $\Delta \Delta \mathrm{C}_{\mathrm{T}}$ method was used as described by Livak and Schmittgen (2001).

\section{Statistical analyses}

Analysis of variance (ANOVA) was performed with the assumption of homogeneity of variance using SAS software (SAS 1990). The results were analyzed in a $2 \times 3$ factorial design with DE and CP and their interaction included as the main effects. Statistically significant differences were identified using Tukey's multiple-range test at $P<0.05$.

\section{RESULTS \\ Diet intake and kid growth}

The DE level of the diet had no significant effect on final weight, slaughter weight, average daily gains (ADG), total dry matter feed intake, or feed conversion ratio (FCR) (Table 3). On the other hand, the CP level of the diet significantly affected ADG and FCR $(P<0.05)$. Goats fed the concentrate-based diet with $17 \%$ CP had a significantly $(P<0.05)$ higher ADG $(77.24 \pm 3.66 \mathrm{~g})$ and better FCR $(6.76 \pm 0.40)$ than

Table 3 Effects of nutritional levels of diets on growth performance in Hainan black goats

\begin{tabular}{|c|c|c|c|c|c|c|c|c|c|c|}
\hline \multirow{2}{*}{$\begin{array}{l}\mathrm{CP}(\%) \\
\mathrm{DE}(\mathrm{MJ} / \mathrm{kg})\end{array}$} & \multicolumn{3}{|c|}{15} & \multicolumn{3}{|c|}{17} & \multirow[t]{2}{*}{ SEM } & \multicolumn{3}{|c|}{$P$-values† } \\
\hline & 11.72 & 12.55 & 13.39 & 11.72 & 12.55 & 13.39 & & $\mathrm{P}$ & $\mathrm{E}$ & $P \times E$ \\
\hline \multicolumn{11}{|l|}{ Live weight (kg) } \\
\hline Initial & 10.56 & 10.53 & 10.67 & 10.50 & 10.56 & 10.56 & 0.02 & 0.94 & 0.99 & 0.99 \\
\hline Final & 16.88 & 16.69 & 16.42 & 16.63 & 17.44 & 17.88 & 0.23 & 0.27 & 0.84 & 0.49 \\
\hline Slaughter $\ddagger$ & 15.42 & 15.75 & 15.92 & 15.83 & 16.67 & 16.25 & 0.24 & 0.83 & 0.64 & 0.16 \\
\hline ADG (g/day) & 70 & 68 & 66 & 68 & 76 & 81 & 1 & 0.02 & 0.48 & 0.66 \\
\hline \multicolumn{11}{|l|}{ Feed intake (g/day) } \\
\hline Concentrate, as fed & 281 & 289 & 274 & 284 & 288 & 285 & 2 & 0.16 & 0.08 & 0.29 \\
\hline King grass (dry matter) & 240 & 231 & 239 & 232 & 246 & 235 & 2 & 0.79 & 0.89 & 0.15 \\
\hline Total dry matter & 521 & 520 & 513 & 516 & 535 & 520 & 3 & 0.38 & 0.37 & 0.47 \\
\hline FCR & 7.48 & 7.65 & 7.30 & 6.97 & 7.04 & 6.47 & 0.17 & 0.03 & 0.39 & 0.89 \\
\hline
\end{tabular}

ADG, average daily gains; FCR, feed conversion ratio. $†$ P and $\mathrm{E}$ means influence factors of crude protein levels and digestible energy levels in the diet, respectively. $\ddagger$ After $16 \mathrm{~h}$ of fasting. 
Table 4 Effects of nutritional level of diets on meat quality in Hainan black goats

\begin{tabular}{|c|c|c|c|c|c|c|c|c|c|c|}
\hline \multirow{2}{*}{$\begin{array}{l}\mathrm{CP}(\%) \\
\mathrm{DE}(\mathrm{MJ} / \mathrm{kg})\end{array}$} & \multicolumn{3}{|c|}{15} & \multicolumn{3}{|c|}{17} & \multirow[t]{2}{*}{ SEM } & \multicolumn{3}{|c|}{$P$-values +} \\
\hline & 11.72 & 12.55 & 13.39 & 11.72 & 12.55 & 13.39 & & $\mathrm{P}$ & E & $\mathrm{P} \times \mathrm{E}$ \\
\hline \multicolumn{11}{|c|}{ Longissimus dorsi muscle } \\
\hline Drip loss (\%) & 1.63 & 1.79 & 1.47 & 1.76 & 1.61 & 1.68 & 0.03 & 0.73 & 0.74 & 0.55 \\
\hline $\mathrm{pH}_{45 \min }$ & $6.54^{\mathrm{a}}$ & $6.44^{\mathrm{ab}}$ & $6.51^{\mathrm{ab}}$ & $6.52^{\mathrm{ab}}$ & $6.15^{\mathrm{b}}$ & $6.57^{\mathrm{a}}$ & 0.02 & 0.22 & 0.02 & 0.11 \\
\hline $\mathrm{pH}_{24 \mathrm{~h}}$ & $5.47^{\mathrm{ab}}$ & $5.33^{\mathrm{ab}}$ & $5.24^{\mathrm{b}}$ & $5.52^{\mathrm{a}}$ & $5.47^{\mathrm{a}}$ & $5.37^{\mathrm{ab}}$ & 0.01 & 0.05 & 0.04 & 0.94 \\
\hline IMF (\%) & 6.83 & 7.21 & 7.30 & 6.46 & 6.55 & 6.97 & 0.07 & 0.05 & 0.22 & 0.79 \\
\hline WBSF $(\mathrm{N})$ & $73.83^{\mathrm{a}}$ & $68.16^{\mathrm{c}}$ & $62.58^{\mathrm{e}}$ & $75.71^{\mathrm{a}}$ & $70.92^{\mathrm{b}}$ & $66.07^{\mathrm{d}}$ & 0.09 & $<0.0001$ & $<0.0001$ & 0.17 \\
\hline \multicolumn{11}{|c|}{ Semimembranosus muscle } \\
\hline Drip loss (\%) & 1.78 & 2.14 & 1.78 & 1.58 & 1.67 & 1.59 & 0.10 & 0.20 & 0.62 & 0.82 \\
\hline $\mathrm{pH}_{45 \min }$ & 6.64 & 6.64 & 6.68 & 6.49 & 6.28 & 6.57 & 0.01 & 0.02 & 0.20 & 0.38 \\
\hline $\mathrm{pH}_{24 \mathrm{~h}}$ & $5.70^{\mathrm{a}}$ & $5.60^{\mathrm{a}}$ & $5.16^{\mathrm{b}}$ & $5.54^{\mathrm{a}}$ & $5.53^{\mathrm{a}}$ & $5.44^{\mathrm{ab}}$ & 0.02 & 0.78 & 0.001 & 0.02 \\
\hline IMF (\%) & 6.58 & 6.79 & 7.33 & 6.33 & 6.47 & 6.66 & 0.06 & 0.07 & 0.15 & 0.69 \\
\hline WBSF $(\mathrm{N})$ & $69.02^{\mathrm{d}}$ & $66.06^{\mathrm{e}}$ & $61.69^{\mathrm{f}}$ & $75.05^{\mathrm{a}}$ & $73.31^{\mathrm{b}}$ & $70.49^{c}$ & 0.10 & $<0.0001$ & $<0.0001$ & 0.002 \\
\hline
\end{tabular}

IMF, intramuscular fat; WBSF, Warner-Bratzler shear force. ${ }^{\mathrm{a}, \mathrm{b}}$ Values within a row with different superscripts differ significantly at $P<0.05$. $\dashv \mathrm{P}$ and $\mathrm{E}$ mean influence factors of crude protein levels and digestible energy levels in diets, respectively.

goats fed the concentrate-based diet with $15 \%$ CP (ADG $69.81 \pm 1.21 \mathrm{~g}$, FCR $7.48 \pm 0.17$ ).

\section{Muscle properties}

Drip loss and IMF of LD and SM samples were not affected by CP or DE levels (Table 4). The $\mathrm{pH}_{24 \mathrm{~h}}$ value tended to decrease $(P<0.05)$ with increasing $\mathrm{DE}$ levels. On the other hand, CP levels did not affect $\mathrm{pH}_{24 \mathrm{~h}}$ (Table 4). The WBSF of goat muscle tissue was significantly $(P<0.05)$ affected by $\mathrm{CP}$ and DE levels (Table 4). The shear force of LD and SM increased with increasing CP levels; the goat fed the concentratebased diet with CP of $17 \%$ and DE of $11.72 \mathrm{MJ} / \mathrm{kg}$ had the highest WBSF $(P<0.05)$. With increasing DE levels, WBSF was reduced $(P<0.05)$.

\section{H-FABP mRNA expression levels}

The CP and DE levels significantly affected the mRNA expression levels of H-FABP in LD and SM $(P<0.05)$ (Fig. 1). The H-FABP mRNA expression levels in LD and SM increased with increasing DE levels $(P<0.05)$, but decreased with increasing CP levels $(P<0.05)$. Goats fed the concentrate-based diet with CP of $15 \%$ and DE of $13.39 \mathrm{MJ} / \mathrm{kg}$ had the highest $\mathrm{H}-\mathrm{FABP}$ mRNA expression levels $(P<0.05)$. Goats fed the concentrate-based diet with $\mathrm{CP}$ of $17 \%$ and $\mathrm{DE}$ of $11.72 \mathrm{MJ} / \mathrm{kg}$ had the lowest H-FABP mRNA expression levels $(P<0.05)$.

\section{CAST and $\mu$-calpain mRNA expressions levels}

The mRNA expression levels of CAST in LD and SM increased with increasing $\mathrm{CP}$ levels $(P<0.05)$ and decreased with increasing DE levels $(P<0.05)$ (Fig. 2). Goats fed the concentrate-based diet with CP of $17 \%$ and DE of $11.72 \mathrm{MJ} / \mathrm{kg}$ had the highest CAST mRNA expression levels $(P<0.05)$.
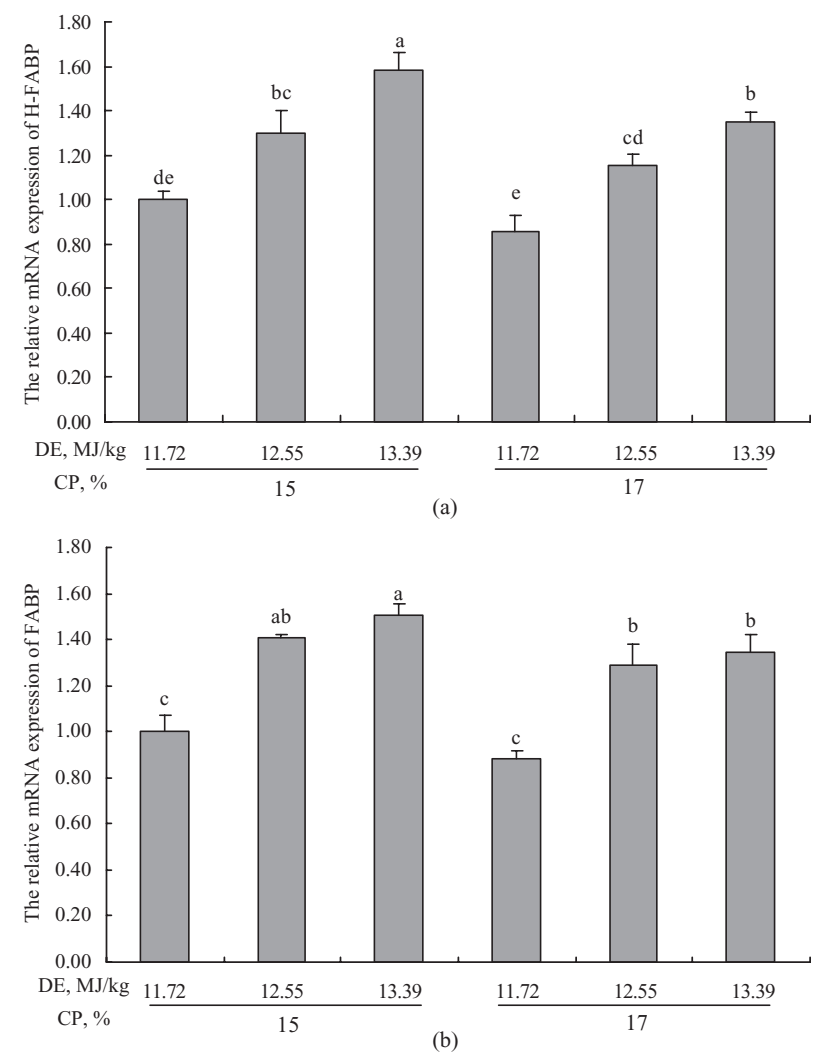

Figure 1 Relative heart fatty acid binding protein (H-FABP) mRNA expression levels. Data are expressed as means \pm SD $(n=4)$. Different superscripts indicate significant difference at $P<0.05$. (a) Relative H-FABP mRNA expression levels in goat Semimembranosus muscle (SM). $P$-values of the main effects are: crude protein $(C P), P=0.0002$; digestible energy (DE), $P<0.0001$; and $C P \times D E, P=0.51$. (b) Relative H-FABP mRNA expression levels in goat Longissimus dorsi (LD). $P$-values of the main effects are $\mathrm{CP}, P=0.0003$; $\mathrm{DE}$, $P<0.0001$ and $C P \times D E, P=0.78$. 


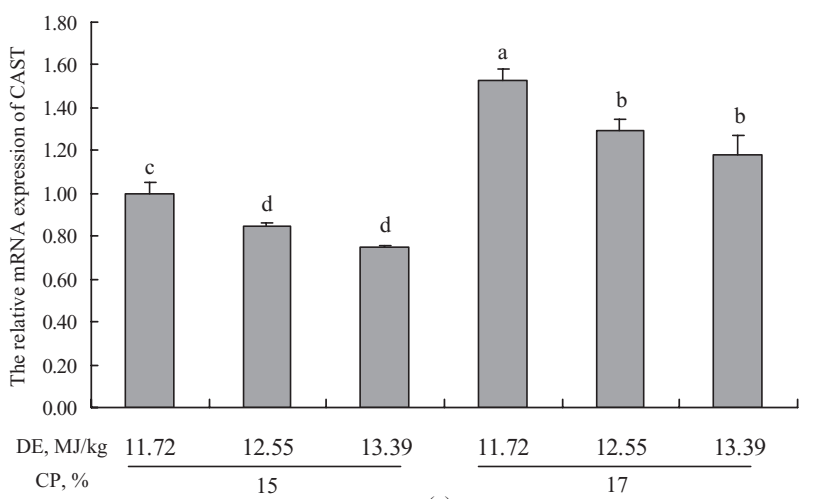

(a)

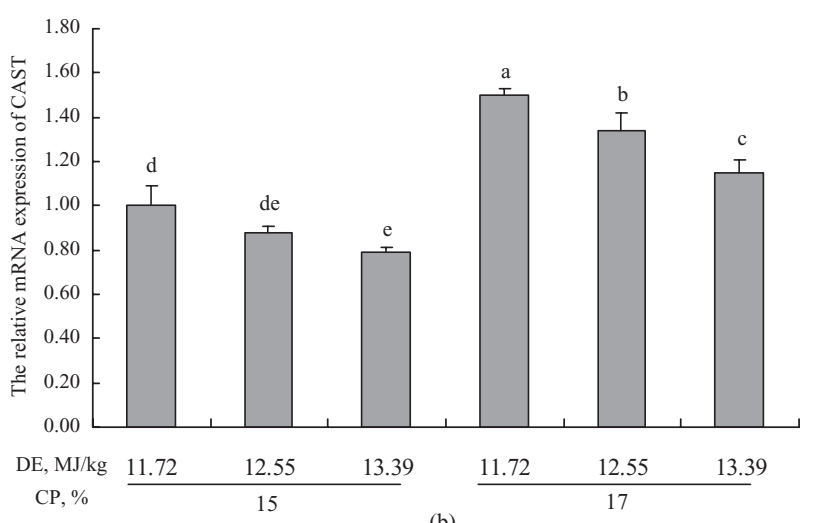

(b)

Figure 2 Relative calpastatin (CAST) mRNA expression levels. Data are expressed as mean \pm SD $(n=4)$. Different superscripts indicate significant difference at $P<0.05$. (a) Relative CAST mRNA expression levels in goat Semimembranosus muscle (SM). $P$-values of the main effects are: crude protein $(C P), P<0.0001 ; D E, P<0.0001$; and $\mathrm{CP} \times \mathrm{DE}, P=0.18$. (b) Relative CAST mRNA expression levels in goat Longissimus dorsi (LD). $P$-values of the main effects are $\mathrm{CP}, P<0.0001 ; \mathrm{DE}, P<0.0001$; and $\mathrm{CP} \times \mathrm{DE}, P=0.04$.

In contrast, goats fed the concentrate-based diet with $\mathrm{CP}$ of $17 \%$ and DE of $11.72 \mathrm{MJ} / \mathrm{kg}$ had the lowest $\mu$-calpain mRNA expression levels $(P<0.05)$ (Fig. 3) and goats fed the concentrate-based diet with $\mathrm{CP}$ of $15 \%$ and DE of $13.39 \mathrm{MJ} / \mathrm{kg}$ had the highest $\mu$-calpain mRNA expression levels $(P<0.05)$. The CAST and $\mu$-calpain mRNA expressions levels in LD and SM were affected significantly $(P<0.05)$ by CP and DE levels in the diet (Figs 2,3).

\section{DISCUSSION}

\section{Effect of the nutritional level of diets on kid growth performance}

The nutritional levels used in this study were based on the nutritional requirements of goats living in developing countries (BW $10 \mathrm{~kg}$, ADG $75 \mathrm{~g}$ ) as reported by Keral (1982) and obtained similar growth performances. In the present study, the CP level of the diet influenced ADG and FCR significantly, and DE level in

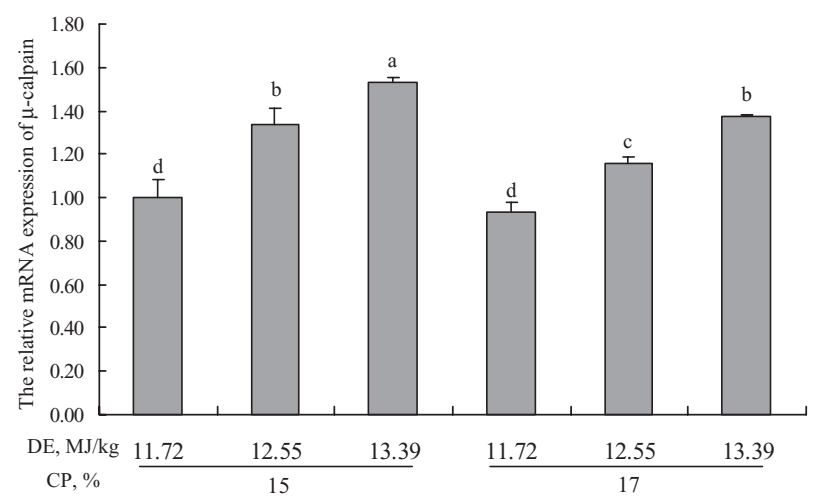

(a)

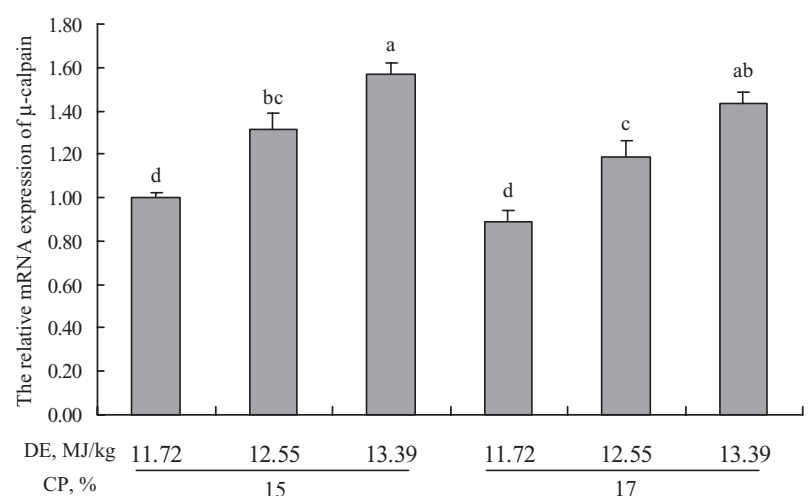

(b)

Figure 3 Relative $\mu$-calpain mRNA expression levels. Data are expressed as mean \pm SD $(n=4)$. Different superscripts indicate significant difference at $P<0.05$. (a) Relative $\mu$-calpain mRNA expression levels in goat Semimembranosus muscle (SM). $P$-values of the main effects are: crude protein (CP), $P<0.0001$; digestible energy (DE), $P<0.0001$; and $\mathrm{CP} \times \mathrm{DE}, P=0.05$. (b) Relative $\mu$-calpain mRNA expression levels of goat Longissimus dorsi (LD). $P$-values of the main effects are $C P, P=0.0006 ; D E, P<0.0001$; and $C P \times D E$, $P=0.94$.

the diet had no significant effect on the growth performance of goats. This may be due to the fact that post-natal growth performance of Hainan black goat is slow and does not response to high energy. The kids may require high protein between 3 and 6 months of age to develop muscle mass, and during the remainder of their growth period, muscle development decreases in favor of fat synthesis. Studies have reported that concentrate-based diets with high nutritional levels result in better goat growth performance. MajdoubMathlouthi et al. (2013) reported that lambs receiving large concentrate diets $(600 \mathrm{~g})$ had high ADG and improved feed conversion rates (FCR).

\section{Effects of the nutritional level of diets on kid meat quality}

The present study indicated that the nutritional levels of the diets had no significant effect on the drip loss of goat muscle. This was similar to the results by Guo 
et al. (2011), who reported that different proteincarbohydrate ratios in the diet had no significant effect on the drip loss of pig muscle. Abdullah and Musallam (2007) also reported that drip loss was not affected by the energy contents of diets fed to male black goats.

Generally, muscle $\mathrm{pH}$ values are reduced during the immediate postmortem period; the rate of $\mathrm{pH}$ decline usually has remarkable effects on meat quality (Diaz et al. 2002). In the present study, the muscle $\mathrm{pH}_{24 \mathrm{~h}}$ values were within or near the acceptable range for goats ( $\mathrm{pH}$ range: 5.6-5.8) (Pratiwi et al. 2007). Furthermore, the results revealed that the $\mathrm{pH}_{24 \mathrm{~h}}$ values declined $(P<0.05)$ with increasing DE levels in the diet. Kadim et al. (2006) reported that increased energy intake leads to increased glycogen storage. Stored glycogen can be used in glycolysis, a pathway that is responsible for low ultimate $\mathrm{pH}$ values.

IMF is important for evaluating meat quality. IMF influences the juiciness, flavor and tenderness of meat. Sanudo et al. (2000) reported that meat from concentrate-supplemented goats had higher IMF content than unsupplemented goats. Young goats (3-6 months of age) mainly develop muscle mass, so the nutritional level of CP and DE had no significant effects on IMF content in goat muscle tissue in the present study. Meanwhile, the IMF content tended to increase with increasing DE levels and declined with increasing CP levels. These results are similar to those obtained in pigs. The IMF content in pig muscle tissue increased with low protein diets (Guo et al. 2011). The energetic efficiency of dietary protein is lower than that of starch, a carbohydrate (Van Milgen et al. 2001); therefore, reducing the protein/carbohydrate ratio increased the amount of energy available for fat deposition.

Tenderness is one of the most important factors influencing meat acceptability (Boleman et al. 1997). Apple et al. (2004) reported that low-protein diets improved tenderness. This could be attributed to an increase in IMF content and to enhanced myofibrillar protein degradation. In the present study, WBSF of goats fed the concentrate-based diet with $15 \% \mathrm{CP}$ was lower than that of the goats fed the concentrate-based diet with 17\% CP. Furthermore, WBSF declined with increasing DE levels, which is consistent with our research findings that IMF tended to increase with increasing DE levels. De Vol et al. (1988) and Hodgson et al. (1991) both reported that high IMF levels contribute to a significant reduction of WBSF in pigs.

\section{Effect of the nutritional levels of diets on the mRNA expression of genes associated with meat quality}

The FABP family comprises a group of small cytosolic proteins. FABP is involved in the intracellular transport of fatty acids to fat storage sites or energy production sites (Krag etal. 2007). H-FABP has been associated with IMF content in pigs (Gerbens et al. 1999). H-FABP is widely distributed, and the heart and skeletal muscle have the greatest expression levels ( $\mathrm{Li}$ et al. 2007). In this study, H-FABP mRNA expression levels tended to increase with increasing IMF and DE levels, which is in agreement with the results obtained by Gerbens et al. (2001) who reported that H-FABP mRNA levels were positively correlated with IMF content. On the other hand, H-FABP mRNA expression levels declined with increasing $\mathrm{CP}$ levels which is in agreement with the results obtained by Guo et al. (2011) who reported that low-protein diets increase IMF content and H-FABP mRNA expression levels in pig muscle tissue.

Tenderness is the most important meat quality. The main factor that determines tenderness is the extent of protein proteolysis in muscle fibers (Koohmaraie $\delta$ Geesink 2006). Calpains, which belong to the protease family, play a role in meat quality. As calpain activity increases, meat tenderness increases (Sentandreu et al. 2002). Geesink et al. (2006) reported that $\mu$-calpain, as opposed to m-calpain, is largely responsible for the myofibrillar protein degradation in skeletal muscle. CAST is the calpain-specific endogenous inhibitor (Wendt et al. 2004). Calpain systems are likely to be affected by the nutritional level of the diet (Thomson et al. 1997); research has indicated that there was a weak positive association between calpastatin activity and protein gain in weaned wether lambs. The results were similar to our study; in the present study, CAST mRNA expression levels significantly increased with increasing CP levels and significantly decreased with increasing DE levels. Interestingly, the $\mu$-calpain mRNA expression levels were in contrast to the CAST mRNA expression levels: $\mu$-calpain mRNA expression significantly increased with increasing DE levels and significantly decreased with increasing CP levels. These results may be attributed to the fact that CAST is a calpain-specific endogenous inhibitor (Wendt et al. 2004). Studies have reported that diets of low nutritional level had a trend to increase IMF content, and decreased WBSF of pork and improved mRNA level of $\mu$-calpain in skeletal muscle (Tang et al. 2010). These results suggested that a moderately reduced energy and protein diet could increase meat tenderness and intramuscular fat.

The nutritional levels of diets can influence the metabolism, synthesis and functional properties of collagen (McCormick 1989), which may be partly due to the up- or down-regulation of genes associated with lipid and protein metabolism in the muscle. These genes may have an effect on IMF content and meat tenderness.

\section{Conclusions}

The CP level of concentrate-based diet did influence the ADG and FCR. Concentrate-based diet with low 
nutritional levels increased muscle meat tenderness in Hainan black goats. The changes in muscle meat tenderness as a result of the nutritional levels of the diet were similar to those reported in other studies. These results suggested that the nutritional level of the diet affects meat quality of Hainan black goats; the results may be explained at least in part by the changes in mRNA expression levels of H-FABP, CAST and $\mu$-calpain.

\section{ACKNOWLEDGMENTS}

This work was supported by the National Nonprofit Institute Research Grant from CATAS-TCGRI of China (Grant No.1630032012021) and the National Public Benefit (Agricultural) Research Foundation of China (Grant No.201203072).

\section{REFERENCES}

Abdullah AY, Musallam HS. 2007. Effect of different levels of energy on carcass composition and meat quality of male black goats kids. Livestock Science 107, 70-80.

AOAC. 2000. International Official Methods of Analysis, 17th edn. Association of Official Analytical Chemists, Gaithersburg, MD

Apple JK, Maxwell CV, Brown DC, Friesen KG, Musser RE, Johnson ZB, Armstrong TA. 2004. Effects of dietary lysine and energy density on performance and carcass characteristics of finishing pigs fed ractopamine. Journal of Animal Science 82, 3277-3287.

Boleman SJ, Boleman SL, Miller RK, Taylor JF, Cross HR, Wheeler TL, et al. 1997. Consumer evaluation of beef of known categories of tenderness. Journal of Animal Science 75, 1521-1524.

De Vol DL, McKeith FK, Bechtel PJ, Novakofski J, Shanks RD, Carr TR. 1988. Variation in composition and palatability traits and relationshipsbetween muscle characteristics and palatability in a random sample of pork carcasses. Journal of Animal Science 66, 385-395.

Diaz MT, Velasco S, Caneque V, Lauzurica S, Ruiz de Huidobro F, Perez C, et al. 2002. Use of concentrate or pasture forfattening lambs and its effect on carcass and meat quality. Small Ruminant Research 43, 257-268.

Geesink GH, Kuchay S, Chishti AH, Koohmaraie M. 2006. Micro-calpain is essential for postmortem proteolysis of muscle proteins. Journal of Animal Science 84, 2834-2840.

Gerbens F, Van Erp AJ, Harders FL, Verburg FJ, Meuwissen TH, Veerkamp JH, Te Pas MF. 1999. Effect of genetic variants of the heart fatty acid-binding protein gene on intramuscular fat and performance traits in pigs. Journal of Animal Science 77, 846-852.

Gerbens F, Verburg FJ, Van Moerkerk HT, Engel B, Buist W, Veerkamp JH, Te Pas MF. 2001. Associations of heart and adipocyte fatty acid-binding protein gene expressionwith intramuscular fat content in pigs. Journal of Animal Science 79, 347-354.

Goll DE, Thompson VF, Li HQ, Wei W, Cong JY. 2003. The calpain system. Physiological Reviews 83, 731-801.

Guo X, Tang R, Wang W, Liu D, Wang K. 2011 . Effects of dietary protein/carbohydrate ratio on fat deposition and gene expression of peroxisome proliferator activated receptor $\gamma$ and heart fatty acid-binding protein of finishing pigs. Livestock Science 140, 111-116.
Hocquette JF, Gondret F, Baeza E, Medale F, Jurie C, Pethick DW. 2010. Intramuscular fat content in meat-producing animals:development, genetic and nutritional control, and identification of putative markers. Animal 4, 303319.

Hodgson RR, Davis GW, Smith GC, Savell JW, Cross HR. 1991. Relationships between pork loin palatability traits and physical characteristics of cooked chops. Journal of Animal Science 69, 4858-4865.

Kadim IT, Mahgoub O, Al-Kindi A, Al-Marzooqi W, Al-Saqri NM. 2006. Effects of transportation at high ambient temperatures on physiological responses, carcass and meat quality characteristics of three breeds of Omani goats. Meat Science 73, 626-634.

Kannan G, Gadiyaram KM, Galipalli S, Carmichael A, Kouakou B, Pringle TD, et al. 2006. Meat quality in goats as influenced by dietary protein and energy levels, and postmortem aging. Small Ruminant Research 61, 45-52.

Keral LC. 1982. Nutrient Requirements of Ruminants in Developing Countries. International Feedstuff Institute, Utah Agricultural Experiment Station, Utah State University, Logan, UT.

Koohmaraie M, Geesink GH. 2006. Contribution of postmortem muscle biochemistry to the delivery of consistent meat quality with particular focus on the calpain system. Meat Science 74, 34-43.

Kosum N, Alcicek A, Taskin T, Onenc A. 2003. Fattening performance and carcass characteristics of Saanen and Bornova male kids under an intensive management system. Czech Journal of Animal Science 48, 379-386.

Krag MB, Gormsen LC, Guo Z, Christiansen JS, Jensen MD, Nielsen S, Jørgensen JO. 2007. Growth hormone-induced insulin resistance is associated with increased intramyocellular triglyceride content but unaltered VLDL-triglyceride kinetics. American Journal of PhysiologyEndocrinology and Metabolism 292, E920-E927.

Li B, Zerby HN, Lee K. 2007. Heart fatty acid binding protein is up regulated during porcine adipocyte development. Journal of Animal Science 85, 1651-1659.

Livak KJ, Schmittgen TD. 2001. Analysis of relative gene expression data using real-time quantitative PCR and the 2(-Delta Delta C(T)) Method. Methods 25, 402-408.

Majdoub-Mathlouthi L, Saïd B, Say A, Kraiem K. 2013. Effect of concentrate level and slaughter body weight on growth performances, carcass traits and meat quality of Barbarine lambs fed oat hay based diet. Meat Science 93, 557-563.

McCormick RJ. 1989. The influence of nutrition on collagen metabolism and stability. Reciprocal Meats Conference 42, 137-148.

Mushi DE, Eik LO, Thomassen MS, Sorheim O, Adnoy T. 2008. Suitability of Norwegian short-tail lambs, Norwegian dairy goats and Cashmere goats for meat production - carcass, meat, chemical andsensory characteristics. Meat Science 80, 842-850.

Patterson JM, Lambert BD, Muir JP, Foote AP. 2009. Effects of protein and energy supplementation on growth, forage intake, forage digestion and nitrogen balance in meat goat kids. Animal 3, 1109-1113.

Pratiwi NMW, Murray PJ, Taylor DG. 2007. Feral goats in Australia: a study on the quality and nutritive value of their meat. Meat Science 75, 168-177.

Sanudo C, Alfonso M, Sanchez A, Delfa R, Teixeira A. 2000. Carcass and meat quality in light lambs from different fat 
classes in the EU carcass classification system. Meat Science 56, 89-94.

SAS. 1990. SASISTAT® User's Guide, Version 6, 4th edn. SAS Institute, Cary, NC.

Sentandreu MA, Coulis G, Ouali A. 2002. Role of muscle endopeptidases and their inhibitors in meat tenderness. Trends in Food Science and Technology 13, 400-421.

Tang R, Yu B, Zhang K, Guo X, Tian G, Huang Z, et al. 2010. Effects of nutritional level on pork quality and gene expression of micro-calpain and calpastatin in muscle of finishing pigs. Meat Science 85, 768-771.
Thomson SC, Hosking BJ, Sainz RD, Oddy VH. 1997. The effect of nutritional status on protein degradation and components of the calpain system in skeletal muscle of weaned wether lambs. The Journal of Agricultural Science 129, 471-477.

Van Milgen J, Noblet J, Dubois S. 2001. Energetic efficiency of starch, protein and lipid utilization in growing pigs. Journal of Nutrition 131, 1309-1318.

Wendt A, Thompson VF, Goll DE. 2004. Interaction of calpastatin with calpain: a review. Biological Chemistry 385 , 465-472. 